To cite this article: Desdemoustier, J., Crutzen N., Cools, M., \& Teller, J. (2019). Smart City appropriation by local actors: An instrument in the making. Cities https://doi.org/10.1016/j.cities.2019.03.021

\title{
Smart City appropriation by local actors: an instrument in the making
}

The literature on Smart Cities lacks of research on how actors understand and appropriate the Smart City. This paper questions in an innovative way their appropriations of the phenomenon. Smart City is considered as an instrument, following the theory of Lascoumes and Le Galès (2007). Is the Smart City a functional instrument: a kind of evidence and a pragmatic solution at disposal or a public policy instrument: not neutral, provoking debates and influencing policies? An empirical analysis is carried on based on a survey among 193 Belgian actors active in the domain. The results show that the Instrument theory is relevant to analyse the actors' appropriation, which do not follow a homogeneous trend. In fact, each actor follows his own logics which will be interesting to study.

Keywords : Smart City; Instrument; Actors; Appropriation; Belgium 


\section{Introduction}

Since the mid-2000s, the Smart City has become a dominant discourse as a new approach to mitigate and remedy current urban problems and societal challenges (Alawadhi et al., 2012). At the European level, the ambition to transform cities and territories to smart places is of some importance (Luque-Ayala \& Marvin, 2015). Research and policy projects have emerged to deal with various issues of the Smart City (Yigitcanlar, 2017). Caragliu and Del Bo (2018a) show strong evidence of a positive association between investing in Smart City policies and Urban GDP growth. Their empirical results show that Smart City policies foster economic performance and that cities engage in Smart City development as a way to address local challenges. The local context conditions are a crucial determinant (Caragliu \& Del Bo, 2018a). However, the literature on Smart Cities identified that such initiatives encompass several technical, managerial, and governance challenges arising from the inherent nature of a Smart City (Manville et al., 2014; Praharaj, Han, \& Hawken, 2018). This article aims to explore how the different actors of a territory appropriate the Smart City and its orientations. It is necessary to understand how the Smart City is encompassed by actors who composed it before trying to act on their behaviours.

The literature on Smart Cities lacks research on how actors understand and appropriate the Smart City. The phenomenon is often perceived as a development of the territory pushed, on the one hand by technologies and, on the other hand, by a holistic development which may include a whole series of notions such as sustainability, governance, human-centricity, public value creation, citizen participation ... In an innovative way, this paper stands out from these conceptualizations and uses the Instrument theory developed by Lascoumes \& Le Gales (2007) as the framework of analysis. According to this conceptual framework, the Smart City may either be considered as a functional instrument: a kind of evidence, a denaturalized technical object, and a pragmatic solution at disposal or as a public policy instrument: not neutral, provoking debates on political goals, influencing policies, affecting actor's resources.

Our empirical study questions the appropriation of Smart City by practitioners. It is based on an online survey amongst 193 respondents so as to offer a picture of the different approaches adopted by Belgian actors active in this domain. Three statistical treatmentscross tabulation, Principal Component Analysis (PCA) and K-sorting-offer several angles of approach to analyse the opinion collected among five categories of Belgian actors. The results 
show that the Instrument theory is relevant to analyse the actors' appropriation of the Smart City, which does not follow a homogeneous trend. In fact, each actor follows his own logic, which will be interesting to study. Future research may investigate the influence of the actor's role in the decision-making process, actors' level of development in Smart City initiatives (mature versus emerging) and actors' ideological background. Most importantly, regarding the Smart City as an instrument calls for more research about the evolution of the position and perception of actors all along the design to the implementation of Smart City policies.

\section{Literature review on Smart City conceptions}

The concept of Smart Cities is composed of numerous components that are differently highlighted. Depending on the definition, it comprises specific features like enhancing the quality of life, adopting ICTs in urban systems, implementing new governance, focusing on human capital, favouring public value creation, supporting innovation and reaching a more sustainable territory (Batty et al., 2012; Bolívar, 2017; Caragliu \& Del Bo, 2018b; Ibrahim, El-Zaart, \& Adams, 2018; Ramaswami, Russell, Culligan, Sharma, \& Kumar, 2016). A techno-centric understanding of the Smart City first emerged in the literature with a productoriented angle that emphasized an interconnection between the market and the urban systems with a strong positioning of service and consulting companies. Solutions against the 'sick city' are pushed by firms (Söderström, Paasche, \& Klauser, 2014). These corporate discourses focus on reimagined ICT tools as management systems for cities. Smart Cities are advertised as the future of globalization (Araya, 2015a). Nevertheless, a critical work in the literature stresses the neo-liberal ethos underpinning this conception of Smart City (Greenfield, 2013; Hollands, 2015; Kitchin, 2015; Vanolo, 2014). Issues such as panoptic surveillance, technocratic and corporate forms of governance or technological lock-ins are argued (Greenfield, 2013; Kitchin, 2014; Townsend, 2013).

Meanwhile, facing these corporate and technological trends in Smart Cities, the development of a holistic Smart City composed of various concepts is fostered in the literature (Mora, Bolici, \& Deakin, 2017). As primarily a counter-reaction, a human conception of the Smart City is advanced (Chatfield \& Reddick, 2015; Gil-Garcia, Pardo, \& Nam, 2015; Marsal-Llacuna \& Wood-Hill, 2017). Social infrastructure (intellectual capital and social capital) is considered as an indispensable endowment for people and their relationships in a Smart City. It comprises various factors such as affinity for lifelong 
learning, social and ethnic plurality, flexibility, creativity, cosmopolitanism or open-minded and participation in public life (Albino et al. 2015). Moreover, numerous authors introduce also a reflection on governance as a driver of the phenomenon (Deakin, 2014; Meijer \& Bolivar, 2015; Paskaleva, 2011; Ben Letaifa, 2015). There is a dominant belief that the transformation of governance is desirable and necessary to make cities smart and to create public value in the context of Smart Cities (Bolívar, 2017). Kourtit and Nijkamp (2012) argue that 'smart governance' implies pro-active and open-minded structures. Actors' collaborations in the Smart City governance are advocated with the principles of participatory design (Paskaleva, Cooper, Peterson, \& Götz, 2015). Participatory governance makes cities smarter and more efficient. It also means that cities that foster the co-participation of public and private institutions in smart projects make such projects more prone to success (Rodríguez Bolívar, 2018).

However, empirical evidence shows that the opening of governance structure to the various actors in the Smart City dynamics is not concretely operated. Angelidou (2017) examines the Smart City plans of 15 world-wide major cities; she shows that they are mainly focusing on ICT as the key factor to foster urban innovation. Her critical review highlights, on the one hand, a lack of bottom-up approaches and actor involvement and, on the other hand, a general disregard of local conditions. On his side, Bolívar (2017) concludes after a study of 64 cities that Smart City actors are not in favour of citizen participation, which could influence the creation of public value in smart cities.

The growth of Smart Cities has to force governments to focus their efforts on increasing public value creation. The active engagement of citizens and actors in urban governance helps to create higher public value. For local governance to be truly effective, it is essential that public managers and politicians engage citizens in open and participative information-sharing and decision-making (Bolívar, 2017). Governance and collaboration are crucial for smarter cities; they reflect how public value can be generated with the participation of citizens and other social actors (Gil-Garcia, Zhang, \& Puron-Cid, 2016).

Another notion complements the holistic conceptualisation of the Smart City: sustainability. This has become one of the central topics of contemporary debates with a focus on resolving social and environmental problems. Sustainable and wise management of natural urban resources, in fact, is a necessary condition for the development of territories. The depletion of natural resources can seriously affect the availability of production factors for 
future generations (Caragliu \& Del Bo, 2018a). The term Sustainable City emerged; cities have become the focal points of sustainable development because they represent major consumers and distributors of goods and services (Bătăgan, 2011). Most of the literature typically finds that a compact urban form is more sustainable, and, therefore, conducive to a better long-run economic performance. Scholars started to consider the term 'Smart Sustainable Cities' and incorporate the different aspects of sustainability in the Smart City concept (Ahvenniemi, Huovila, Pinto-Seppä, \& Airaksinen, 2017; Araya, 2015b; Garau \& Pavan, 2018; Girard, 2013; Ibrahim et al., 2018; Kramers, Höjer, Lövehagen, \& Wangel, 2014; Dameri 2013; Rai \& Challa, 2016). The interpretations of urban sustainability have promoted an anthropocentric approach that encourages cities to respond to people's needs by designing sustainable solutions to mitigate social and economic weaknesses (Garau \& Pavan, 2018). Transforming a city into a Smart Sustainable City (SSC) is a continuous long-term process that requires changes to be introduced at all city levels with the help of an SSC roadmap, which provides a high-level view of the objectives and goals of the transformation process and identifies the transformation phases and milestones (Ibrahim et al., 2018). The notion of a smart sustainable city is treated as an ideological dimension dependent on strategic directions, to find a good balance between territories and human societies via ICT and behavioural changes (Cugurullo, 2018). The city must become a powerful generator of value, beginning with its own spatial, social, cultural, and relational resources (Garau \& Pavan, 2018).

There is neither a single template for framing a Smart City, nor a one-size-fits-all definition of the Smart City (O’Grady \& O'Hare, 2012). According to Mora et al. (2017), Smart City research is fragmented and lacks cohesion. Conceptual papers as well as models and frameworks empirically and theoretically developed are significantly produced. Angelidou (2014) and Caragliu \& Del Bo (2016) try for example to identify the main features of Smart City policies, which consist of focusing on core areas of intervention and existing strengths; incorporating a co-ordination between different policy departments; involving actors in the design and implementation of the policies; matching investment of ICTs with physical and institutional changes; and finally operating at a relatively small scale of interventions.

Smart City policies should have a bottom-up, demand-driven component and should be closely monitored by municipalities and local governments (Caragliu \& Del Bo, 2018a). Strategic information on a city's performance is necessary to assess from both an economic 
perspective and from a multidimensional, partly social and ecological perspective, as a complement to traditional measures. There is world-wide (both among academics and practitioners) increasing interest in the development of KPIs and systems for monitoring and sharing detailed information on trends and city achievements (Kourtit \& Nijkamp, 2018). The management and strategic governance of modern cities calls for professional and informed decision-support tools. In this context, city-dashboard implementation has become very popular as a means to measure the smartness of a city, both to evaluate the reached goals and support further decisions, investments and initiatives (Dameri, 2017). Smart-city dashboard can help to predict and accommodate the daily citizens' needs thanks to data monitoring (Suakanto, Supangkat, Suhardi, \& Saragih, 2013). Supporting the development of smart city governance models, these platforms or interfaces use (big) data to communicate important information on an effective way through user-friendly visualizations (Mannaro, Baralla, \& Garau, 2018). Underpinning the 'top-down visions' of these dashboards, they find a range of sociotechnical engagements, collaborative forums, governance challenges which are negotiated daily by a range of actors both within and outside city administrations (Barns, 2018). Every city can benefit from having a dashboard if it knows what the purpose of it is. A well-implemented dashboard may help enhance the process of becoming a smart city (Mannaro et al., 2018).

More efforts should be undertaken in evaluating the impacts of Smart City programs and initiatives (Caragliu \& Del Bo, 2018b). The literature on Smart Cities identified that such initiatives encompass several technical, managerial, and governance challenges arising from the inherent nature of a Smart City (Manville et al., 2014; Praharaj et al., 2018). The literature lacks a detailed analysis of the management of Smart City initiatives as well as descriptions of the underlying drivers and challenges faced. In particular, the literature on Smart Cities lacks a first research stage based on studies stressing how actors appropriate the Smart City and its different orientations. It is necessary to understand how the Smart City is encompassed by the different actors involved before trying to study its management. Which elements/components of the polymorphic Smart City concept are assimilated and supported by actors? How do actors stand themselves on Smart Cities and what are their views on it? Is the Smart City considered as a tool to build the city or as a policy debate to imagine the future? Identifying actors' interests and appropriations is essential to face the challenges of building and managing the Smart City and its governance. 
Political sociology and sociology of science are solicited to understand the construction of the Smart City and its appropriation by actors. In this perspective, the Smart City is envisaged as an instrument that accounts for processes of public policy change. This notion of instrument is introduced through questions of management and governance of public subsystems of societies and policy networks (Termeer \& Koppenjan, 1997; Lascoumes \& Valluy, 1996) which corresponds to the open and multi-actor governance context of Smart Cities. Political science studies instruments to understand better the linkages between policy formulation and policy implementation, and to gain insights into the public policy decisionmaking process. Public policy instrumentation becomes a major issue, as it reveals a theorization of the relationship between the governing and the governed (Lascoumes \& Le Gales, 2007). In this regard, for some authors, local governments play a crucial role in the efficient adoption of collaborative and/or participative models of governance in Smart Cities (Bătăgan, 2011; Batty et al., 2012) This type of engagement is hardly political in nature and needs new models of governance in cities different from those of traditional bureaucratic governance (Bolívar, 2017). The citizenry and other actors must be considered target groups of the local government creating and using smart technologies to increase their quality of life (Gil-Garcia, Pardo, \& Nam, 2016). For Caragliu and Del Bo (2018b), the decision to implement Smart City policy initiatives and their policy goals should be firmly kept in the hands of local public authorities, based on the involvement of actors, including citizens and local businesses, in partnership with ICT companies providing technical solutions. While for Ben Letaifa (2015), the co-ordination and leadership roles in Smart Cities can shift from one actor to another depending on the identity, resources, and ecosystem readiness.

\section{Theoretical framework}

The Smart City is considered as an instrument that ensures a choice of practical device and some modes of operation. In fact, the Smart City emerged as a new way of imagining, organizing and managing the city and its flows. The question of Smart City as a territorial and societal instrument is framed in this article by the theories of instrumentalization developed by Lascoumes and Le Gales (2007). In this perspective, the Smart City is studied as an instrument that stands between a device utilized to transform the territory and a political issue questioning the future of cities and towns. That helps to understand better the difficulties of implementing the Smart City. 
A multiplication of actors has also been noticed in cities and territories. Some authors considered the city as an ungovernable place that hosts a 'street fighting pluralism' (Yates, 1977). However, the phenomenon of multiplication of actors generates mechanisms of reorganization of relationships between actors. It implies a multiplication and an innovation of public policies instruments (Pinson, 2006). In Smart Cities, actors at all levels are embracing the notion of smartness to distinguish their policies and programmes for targeting sustainable development, economic growth, better quality of life for their citizens, and creating happiness (Ballas, 2013). The emergence of the creation of public value and the need for citizen involvement in Smart Cities entails a substantial change in the management of cities and the need to create innovative forms of governance based on the concept of network governance (Rodríguez-Bolívar, 2015). In this topic, instruments may determine what resources can be used and by whom as well as the forms of collective action. Instruments may be legislative, regulatory, economic, agreement, and fiscal, as well as incentive, informative, and communicative.

An instrument constitutes a device that is both technical and social, that organizes specific social relations between the state and those it is addressed to, according to the representations and meanings it carries. It is a particular type of institution, a technical device with the generic purpose of carrying a concrete concept of the politics/society relationship and sustained by a concept of regulation (Lascoumes \& Le Gales, 2007).

This definition of instrument fits with what Angelidou (2015) considers as smartness, which is a continuum in which local government officials, citizens, and other actors think about and implement initiatives that strive to make a city a better place to live in, 'smarter'. The Smart City is an instrument used by managers, politics, and economics to support specific development policies (Hollands, 2008; Vanolo, 2014).

An instrument orients relations between authorities and civil society through tools and devices (Lascoumes \& Le Gales, 2007). In the literature on Smart Cities, Nam and Pardo highlight three main factors - technologies, people, institutions-which constitute the main components of a Smart City. Associated to each other, they represent a certain form of device that supports the construction of the Smart City. Ben Letaifa (2015) considers that Smart Cities differ from other concepts in offering a balanced centricity among technology, institutions, and people. The expansion of city missions is accompanied by a development and 
diversification of instruments. The public policy instruments are a means of adapting relations between actors through intermediaries in the form of devices that mix technical and social components in a more or less standardized form (Lascoumes \& Le Gales, 2007). It assimilates the factors of the Smart City: technology, people, and institutions.

The classic forms of city government 'command and control' regress due to the multiplication of interactions with the market (privatization in particular) and the forms of actors' collaboration (public-private, contracting, PPP, citizen collaboration). New approaches appear via new public policy instruments where a 'new governance' perspective strives to take into account large networks of heterogeneous actors (private/public, profit/nonprofit) to co-ordinate them better (Bolívar, 2017; Caragliu \& Del Bo, 2018b; Lascoumes \& Simard, 2011; Salamon, 2002). In the literature on Smart Cities, authors promote a holistic ecosystem that allows co-creation among all actors. Smart governance stresses collaboration between the various actors in the city. In this perspective, one actor model is highly prevalent. The four-helix model, suggested by Lombardi et al. (2012) incorporates the outcome of government policies, academic leadership qualities, corporate strategies, and civil society expertise.

An instrument may favour certain actors and interests and exclude others. Actors have capacities for action that differ widely according to the instrument chosen (Lascoumes \& Le Gales, 2007). The 3RC framework developed by Kummitha and Crutzen (2017) highlights a specific Smart City construction that favours several actors. Some privileged actors build a neoliberal Smart City, where the power relations are contained by corporations and governments. They turn the public space into private space and control technological advancements (Critical school of thought). There are also actors that preferentially take part in the construction process of the Smart City. They are present in the consultancy, planning, and building of the Smart Cities on the basis of ICTs, data management, IoT, and technologies (Restrictive school). An instrument influences the way in which actors are going to behave. It creates uncertainties about the effects of the balance of power; they eventually privilege certain actors and interests and exclude others; they constrain actors and they drive forward a certain representation of problems (Gardon, Lascoumes \& Le Galès 2007).

An instrument is never a closed device; it is inseparable from a contextualized mode of appropriation. This appropriation implies some mobilization (like the affirmation of new competencies), some reformulation (in favour of interests and relationships of the power of 
actors) and some resistance (by reducing the scope of the instrument or by circumventing alliances) (Lascoumes \& Simard, 2011). The Smart City is considered an instrument that could be appropriated by actors as either a functionalist instrument (1) or as a public policy instrument (2). For Lascoumes \& Le Gales (2007) there is a considerable difference between a functionalist approach of the instruments - called hereafter 'functionalist instruments' — and a socio-political approach of the instruments—called hereafter 'public policy instruments'.

- The functionalist instruments are considered as a kind of evidence. The choice of tools and modes of operation are superficial. These instruments are viewed as being 'at disposal' and conceived as a pragmatic political and technical approach to solve problems. They are neutral and equally available. The central set of issues is around the effectiveness of instruments. The issue of selecting instruments and their mode of operation is presented as a matter of simple technical choices.

- The public policy instruments are considered as not purely technical, inert, and with perfect axiological neutrality. On the contrary, they are bearers of values, fuelled by interpretation. Instruments tend to produce original and sometimes unexpected effects. They have their own force of action, structure public policy according to their own logic and develop socio-political mobilizations. Instruments also produce a specific representation of the issue they are handling.

The Smart City once viewed as a functionalist instrument (1) promotes a management and regulation of the city that operates via information and analytic systems. This vision promotes a technocratic model of urban governance. It presumes that a city can be measured, monitored, and treated as a technical problem, which can be addressed through technical solutions. It represents what Mattern (2013) calls 'instrumental rationality' and Morozov (2013) names 'solutionism', wherein complex social situations can be disassembled into neatly defined problems that can be solved or optimized (Kitchin, 2014). The functionalist instrument of the Smart City follows a 'hard' direction where ICT and technologies play a decisive role (Albino et al., 2015). Companies offer Smart City solutions against the 'sick' city (Söderström et al., 2014) in developing projects and proof of concepts on the territory. A neoliberal development of the Smart City operates through the promotion of (public)-private ventures as a way to smarten the territory. 
The Smart City once viewed as a public policy instrument (2) is an ideological construct according to which being smarter entails specific strategic directions (Ballas, 2013). In Smart Cities, proposing visions for the city of the future and developing policy instruments to achieve those visions are important capabilities of actors. A Smart City should not be about technologies only but should also consider important management and policy aspects (Chourabi et al., 2011). A Smart City takes also a 'soft' direction integrating elements such as education, culture, social inclusion, and social innovation. In a Smart City, it is important that smartness has not to be considered as a dichotomy in terms of 'being smart' or 'not being smart (Angelidou, 2014). Such an approach stresses questions on introducing a distinction between the 'good' and the 'bad' city (Vanolo, 2014). The Smart City is an example of a 'political assemblage' (Mcfarlane, 2011). Smart Cities as a public policy instrument are a new way to enhance local innovation ecosystems and knowledge economy overall (Schaffers et al., 2011). Smart City policies do tend to make cities more efficient, innovation processes are expected to be fostered, mainly through a general improvement of local knowledge production functions (Caragliu and Del Bo, 2018a, 2018b). Actors discuss and argue how to solve problems of the city with a holistic conception of the solutions to mobilize ranging through participative, collaborative, or self-governing models, depending on the degree of participation of the networking actors and the governance independence of governments (Bolívar, 2017).

The theoretical framework that Lascoumes \& Le Gales (2007) proposed on instruments is an innovative way to approach Smart Cities. This paper studies how actors-politicians and public servants, private actors, members of the civil society and researchers-are appropriating the Smart City between a functionalist instrument (1) and a public policy instrument (2). The assumption made by the authors is that the Smart City may be considered as a functionalist instrument by some actors and as a public policy instrument by others according to their role in the decision-making process, their level of development in Smart City initiatives (mature versus emerging) and their ideological background.

This distinction offers a comprehensive appropriation of the multifaceted Smart City by its practitioners. It also allows an identification of actors' interests through their appropriation of the Smart City. And finally, it permits detection of actors' common and opposite visions of territorial, societal, and practical development of the Smart City. An empirical study questioning actors is established. It validates the theoretical statements on Instruments applying to Smart Cities and the author's assumptions on actors' appropriations. 


\section{Methodology}

To understand the actors' conception of the Smart City, this study directly questions practitioners. Empirical research targeting the thinkers, users, designers, and makers of the concept offers the opportunity to analyse how they appropriate the phenomena in its complexity. The quantitative analyses carried out in this study on the actors' positioning aims to identify how the theoretical Smart City conceptions are handled in practice by actors of the Belgian territory. The study aims at identifying the similarities and differences within and between actors as well as the possible classifications of their appropriations. An innovative canvas based on the theory of instrument frames the results. This empirical research aspires to transcend the traditional examination carried out on the Smart City orientations between human, technology, governance, sustainability, infrastructure, etc. To analyse concretely the actors' appropriation of Smart City, a questionnaire with 31 short statements is redacted on the basis of:

- The three factors of the Smart City: technologies, people, institutions (Nam \& Pardo, 2011)

- The critics presented in the 3RC framework developed by Kummitha \& Crutzen, (2017), especially the critical school of thought and restrictive school.

- Territorial matters stressed by Angelidou (2014) focusing on spatial considerations between the various territorial levels (municipal, regional, and national).

- Actors 'model based on the quadruple helix developed by Lombardi et al. (2012).

These elements are presented in the literature review and in the theoretical framework. The statements encapsulate the different aspects and orientations of the Smart City as well as the interrogations around it and its practices. They allow interviewed actors to position themselves pro or contra the 31 statements (Likert scale from 1 totally disagree to 5 totally agree). The statements are distributed across four sections: General considerations, Technology, Governance, and Territorial Aspects. The 31 statements represent transversal elements which are considered as determinants to study the actors' appropriation of a Smart City. They are data in this empirical analysis and serve as raw materials for the statistical treatments like the actors' categories. Five of them are instituted: Elected politician (1), administrations and public organizations (2), private companies (3), research centres \& universities (4), and associations (5). The study population is limited to the actors which are 
already involved in the Smart City movement in Belgium. The authors decided to build the study on actors who develop certain Smart Cities' knowledge. The objective is to interrogate actors who are at a minimum working on some Smart City aspects in their respective activities. The goal is to take into account their meaning of the Smart City. They are able to express their opinions on the phenomenon. For this purpose, the respective actors are selected through the Belgian society on the basis of their participation in Smart City events, programmes, studies, or competitions. The selection of these Smart City activities allows targeting actors who possess sufficient knowledge of the topic.

The responses of actors were collected through an anonymous online survey. A questionnaire was sent to the different actors in two languages: Dutch and French (Qualtrics). The data collection lasted 3 months (from February to April 2018). 193 responses were collected. There is an equilibrium of respondents across the three Belgian Regions \& the Federal level and across the five actors' categories as shown in Table 1. The numbers of solicitations by e-mails is also indicated, it allows calculating the participation rates for each category of actor. Public organizations and private companies represent the highest number of respondents in comparison to associations and elected politics.

Table 1: Number of actors' respondent in the five categories

\begin{tabular}{|c|l|l|l|l|c|c|}
\hline $\begin{array}{c}\text { Localization/ } \\
\text { Actors' category }\end{array}$ & \multicolumn{1}{|c|}{$\begin{array}{c}\text { Elected } \\
\text { politics }\end{array}$} & $\begin{array}{c}\text { Admin \& } \\
\text { public }\end{array}$ & Private & $\begin{array}{c}\text { Research } \\
\text { centres \& uni }\end{array}$ & $\begin{array}{c}\text { Civil Society } \\
\text { (Assocs) }\end{array}$ & Total \\
\hline Flemish Region & 7 & 11 & 10 & 8 & 4 & $\mathbf{4 0}$ \\
\hline Walloon Region & 5 & 25 & 8 & 9 & 7 & $\mathbf{5 4}$ \\
\hline $\begin{array}{r}\text { Brussels Capital } \\
\text { Region }\end{array}$ & 11 & 8 & 4 & 11 & 14 & $\mathbf{4 8}$ \\
\hline $\begin{array}{c}\text { Belgium } \\
\text { (Whole country) }\end{array}$ & 3 & 9 & 30 & 3 & 6 & $\mathbf{5 1}$ \\
\hline Total & $\mathbf{2 6}$ & $\mathbf{5 3}$ & $\mathbf{5 2}$ & $\mathbf{3 1}$ & $\mathbf{3 1}$ & $\mathbf{1 9 3}$ \\
\hline Sample & 92 & 158 & 240 & 122 & 110 & 722 \\
\hline Response Rates (\%) & 28 & 35 & 22 & 25 & 28 & 27 \\
\hline
\end{tabular}

The actors' distribution takes into account the institutional complexity of the country and the actors' types present in the territory. Three main statistical treatments are planned to dissect the actors' appropriation of the phenomena in its complexity. These statistical methods are conducted independently of each other. They aim to study separately the similarities and differences within and between the five categories of actors as well as the possible classifications of the 31 statements depending on the actors' positioning. 
- The first statistical treatment corresponds to a classical sorting and cross sorting by actors' categories reinforced by ANOVA tests. These calculations provide in Section 5a a global overview of the actors' positioning on the 31 statements. This allows identifying the preference of each actor to determine their appropriation of the Smart City.

- The second statistical treatment consists of a Factor Analysis using the method PCAPrincipal Component Analysis. This multivariate technique, presented in Section 5b, studies the interdependence of the 31 statements according to the actors' responses. The calculation offers a logical grouping of proposals according to the actors' perception of the Smart City. It highlights the different Smart City significations of the interviewed actors.

- The third statistical treatment is based on a K-sort, which identifies relatively homogeneous groups of cases (respondents) based on selected characteristics (31 statements). The results offer, in Section 5c, a classification of actors as a function of their common positions on specific proposals. This allows identifying groups of actors sharing the same perceptions of the Smart City according to the 31 statements.

These treatments are performed using the SPSS software. They aim to offer an overview, on the one hand, on the dynamic into the categories of actors identifying similarities and differences of appropriation in and in-between the five groups, and on the other hand, on the appropriation on statements to determine how actors are positioned on them.

\section{Results}

The results of the crosstabs, PCA and K-sorting offer several angles of approach to analyse the opinion collected from the Belgian actors. These three statistical methods allow deciphering actors' appropriations of the phenomenon; taken together; they will invalidate or confirm the original hypothesis. They offer different types of classification of statements and actors. It will, therefore, be possible to analyse the Smart City as a functional instrument or as a public policy instrument. 


\subsection{Crosstabs: Actor's means}

The crosstabs offer a first exploration of actors' position on the 31 statements and allow identifying their preferences. For the five categories of actors, the mean is calculated for each statement. These means show that actors on average develop similar points of view on some statements while, for others, disagreements exist between actors. Nevertheless, in general on the 31 statements the values stay high (between min 1.83 and max 4.38). Indeed, several statements are acclaimed by the different categories of actors with on average a rating superior to 4-Strongly agree. They highly approve that Smart Cities include green technologies (no. 13: 4.03/5) and is a key technological challenge for cities and towns (no. 10: 4.16/5).

In contrast, two statements receive a strong negative evaluation with on average a value below 2.5, showing a certain disagreement. Actors are mainly opposed to the fact that the Smart City is a menace on regulation and rules of law (no. 8: 2.46) as well as a fashionable concept that may soon be outdated (no. 2: 2.48). In relation to these statements, private companies evaluate this statement (no. 2) with the lowest value, 1.83. out of this statistical treatment (the only evaluation under 2/5). Nevertheless, differences of evaluation exist between actors as well as similar conceptions on the several statements. To study these similarities and differences, the results of a one-way ANOVA comparing the means of actors is available in the last two columns of Table 2. A result smaller than 0.05 in the last column confirms a significant difference of means between actors.

Table 2: Actors' means by statements and results of the ANOVA tests

\begin{tabular}{|c|c|c|c|c|c|c|c|c|c|c|}
\hline$N$ & $\begin{array}{l}\text { Statements } \\
\text { Means of actors' categories }\end{array}$ & $\begin{array}{c}\text { Electe } \\
d \\
\text { politics }\end{array}$ & $\begin{array}{c}\text { Admin } \\
\text { Public } \\
s\end{array}$ & $\begin{array}{c}\text { Private } \\
\mathrm{s}\end{array}$ & $\begin{array}{l}\text { Researc } \\
h \text { \& Uni }\end{array}$ & $\begin{array}{c}\text { Civil } \\
\text { Societ } \\
y\end{array}$ & $\begin{array}{c}\text { Tota } \\
1\end{array}$ & $\operatorname{Min}_{1}^{\operatorname{Max}}$ & $\begin{array}{c}\text { F- } \\
\text { Valu } \\
\text { e }\end{array}$ & $\begin{array}{c}\text { P- } \\
\text { valu } \\
\text { e }\end{array}$ \\
\hline 1 & $\begin{array}{l}\text { Smart City is an essential tool for } \\
\text { branding towns, cities and territories }\end{array}$ & 3.77 & 3.38 & 3.81 & 2.77 & 3.03 & 3.39 & 1.03 & 5.7 & $\begin{array}{c}< \\
0.001\end{array}$ \\
\hline 2 & $\begin{array}{l}\text { Smart City is a fashionable concept } \\
\text { that may soon be outdated }\end{array}$ & 2.31 & 2.68 & 1.83 & 3.19 & 2.68 & 2.48 & 1.37 & 7.7 & $\begin{array}{c}< \\
0.001 \\
\end{array}$ \\
\hline 3 & $\begin{array}{l}\text { Smart City is an essential tool for the } \\
\text { future of cities and towns in Belgium }\end{array}$ & 3.92 & 3.75 & 4.31 & 3.39 & 3.48 & 3.82 & 0.92 & 4.9 & 0.001 \\
\hline 4 & $\begin{array}{l}\text { Smart City is related to the threat of } \\
\text { privatization of public spaces and } \\
\text { public services }\end{array}$ & 2.19 & 2.42 & 2.15 & 3.03 & 3.19 & 2.54 & 1.04 & 5.2 & 0.001 \\
\hline 5 & $\begin{array}{l}\text { Smart City is an essential tool to } \\
\text { enhance the sustainability of cities } \\
\text { and territories }\end{array}$ & 3.92 & 3.79 & 4.38 & 3.61 & 3.61 & 3.91 & 0.77 & 4.1 & 0.004 \\
\hline 6 & $\begin{array}{l}\text { Smart City may further increase } \\
\text { marginalization of some inhabitants } \\
\text { and social failures }\end{array}$ & 3.42 & 3.36 & 2.65 & 3.97 & 3.84 & 3.35 & 1.31 & 7.2 & $\begin{array}{c}< \\
0.001\end{array}$ \\
\hline
\end{tabular}

\footnotetext{
${ }^{1}$ Calculated on the categories of actors' results out of the sample (not based on the aggregate means).
} 


\begin{tabular}{|c|c|c|c|c|c|c|c|c|c|c|}
\hline 7 & $\begin{array}{l}\text { Smart City is an essential tool to } \\
\text { improve the quality of life of } \\
\text { inhabitants }\end{array}$ & 3.85 & 3.70 & 4.04 & 3.55 & 3.65 & 3.78 & 0.49 & 1.3 & 0.281 \\
\hline 8 & $\begin{array}{l}\text { Smart City menaces regulation and } \\
\text { rules of law }\end{array}$ & 2.19 & 2.34 & 2.29 & 2.65 & 2.97 & 2.46 & 0.78 & 2.6 & 0.036 \\
\hline 9 & $\begin{array}{l}\text { Smart City will mobilize considerable } \\
\text { financial resources in the coming } \\
\text { years }\end{array}$ & 3.85 & 3.62 & 3.67 & 4.00 & 3.74 & 3.75 & 0.38 & 0.9 & 0.455 \\
\hline 10 & $\begin{array}{l}\text { Smart City is a key technological } \\
\text { challenge for cities and towns }\end{array}$ & 4.35 & 4.11 & 4.38 & 4.00 & 3.84 & 4.16 & 0.55 & 2.4 & 0.049 \\
\hline 11 & $\begin{array}{l}\text { Smart City is mainly based on the use } \\
\text { of ICT, Big, and Open Data }\end{array}$ & 3.46 & 3.43 & 3.65 & 3.32 & 3.58 & 3.50 & 0.33 & 0.6 & 0.659 \\
\hline 12 & $\begin{array}{l}\text { Smart City is a tool to enhance } \\
\text { transparency in decision-making }\end{array}$ & 2.92 & 3.40 & 3.29 & 3.13 & 3.32 & 3.25 & 0.47 & 0.8 & 0.543 \\
\hline 13 & $\begin{array}{l}\text { Green technologies are part of Smart } \\
\text { Cities solutions }\end{array}$ & 3.77 & 3.98 & 4.29 & 3.97 & 3.94 & 4.03 & 0.52 & 1.4 & 0.230 \\
\hline 14 & $\begin{array}{l}\text { Smart City is a threat: it menaces } \\
\text { privacy protection, facilitates } \\
\text { hacking, ... }\end{array}$ & 2.73 & 2.75 & 2.81 & 3.26 & 3.06 & 2.90 & 0.53 & 1.2 & 0.301 \\
\hline 15 & $\begin{array}{l}\text { Smart City improves governance } \\
\text { principles (Decision-making, actors' } \\
\text { co-operation, ...) }\end{array}$ & 3.19 & 3.11 & 3.06 & 3.23 & 3.13 & 3.13 & 0.17 & 0.2 & 0.956 \\
\hline 16 & $\begin{array}{l}\text { Smart City should be based on } \\
\text { initiatives led by civil society actors } \\
\text { (citizens, associations) }\end{array}$ & 2.96 & 3.19 & 3.25 & 2.94 & 3.29 & 3.15 & 0.35 & 0.9 & 0.474 \\
\hline 17 & $\begin{array}{l}\text { Local government should play a } \\
\text { leading role in the Smart City } \\
\text { development }\end{array}$ & 3.50 & 3.25 & 3.37 & 3.10 & 3.39 & 3.31 & 0.40 & 0.7 & 0.609 \\
\hline 18 & $\begin{array}{l}\text { Smart City construction cannot start } \\
\text { without the setup of a strategic plan }\end{array}$ & 3.35 & 3.11 & 3.71 & 3.17 & 3.48 & 3.38 & 0.60 & 4.2 & 0.003 \\
\hline 19 & $\begin{array}{l}\text { Smart City should entail a sharing of } \\
\text { power between the different actors }\end{array}$ & 3.27 & 3.66 & 3.04 & 3.23 & 3.68 & 3.37 & 0.64 & 1.9 & 0.118 \\
\hline 20 & $\begin{array}{l}\text { Administration is the best actor } \\
\text { positioned to manage local } \\
\text { implementation of Smart City } \\
\text { strategy and solutions }\end{array}$ & 2.88 & 3.09 & 2.88 & 3.00 & 2.94 & 2.97 & 0.21 & 0.2 & 0.915 \\
\hline 21 & $\begin{array}{l}\text { Smart City cannot be developed } \\
\text { without local startups and } \\
\text { entrepreneurs }\end{array}$ & 2.62 & 3.25 & 3.46 & 3.00 & 3.06 & 3.15 & 0.85 & 3.3 & 0.013 \\
\hline 22 & $\begin{array}{l}\text { Research centres and universities are } \\
\text { essential contributors to Smarter } \\
\text { cities and towns }\end{array}$ & 2.92 & 3.13 & 2.96 & 3.45 & 3.29 & 3.13 & 0.53 & 2.3 & 0.059 \\
\hline 23 & $\begin{array}{l}\text { Smart City should be based on a } \\
\text { balanced mix of projects from public } \\
\text { authorities and projects from } \\
\text { citizens, associations, and private } \\
\text { companies }\end{array}$ & 3.08 & 3.30 & 3.60 & 3.42 & 3.61 & 3.42 & 0.54 & 2.7 & 0.030 \\
\hline 24 & $\begin{array}{l}\text { Smart City is primarily a political } \\
\text { process involving elected officials }\end{array}$ & 3.23 & 3.25 & 2.58 & 3.10 & 2.94 & 2.99 & 0.67 & 1.4 & 0.220 \\
\hline 25 & $\begin{array}{l}\text { The development of Smart City is } \\
\text { largely relying on private consultancy }\end{array}$ & 3.38 & 3.09 & 2.98 & 2.94 & 3.06 & 3.07 & 0.45 & 0.4 & 0.808 \\
\hline 26 & $\begin{array}{l}\text { To accelerate the development of the } \\
\text { Smart City, it is important to lighten } \\
\text { the administrative procedures }\end{array}$ & 2.77 & 3.25 & 3.31 & 3.16 & 2.90 & 3.13 & 0.54 & 1.7 & 0.158 \\
\hline 27 & $\begin{array}{l}\text { Large multinationals (IBM, Google, } \\
\text { Uber, Accenture) primarily benefit } \\
\text { from Smart City development }\end{array}$ & 3.15 & 3.06 & 3.27 & 3.35 & 3.32 & 3.22 & 0.30 & 0.4 & 0.810 \\
\hline 28 & $\begin{array}{l}\text { Smart city is directly related to an } \\
\text { increased competition between cities } \\
\text { and territories }\end{array}$ & 2.77 & 2.50 & 2.73 & 2.97 & 3.39 & 2.82 & 0.89 & 3.3 & 0.013 \\
\hline 29 & $\begin{array}{l}\text { Smart City can be adapted to any } \\
\text { territory, including rural areas }\end{array}$ & 3.81 & 3.87 & 4.15 & 4.06 & 3.87 & 3.97 & 0.35 & 0.8 & 0.522 \\
\hline 30 & $\begin{array}{l}\text { Smart City will mainly benefit the } \\
\text { large cities in Belgium }\end{array}$ & 3.62 & 3.17 & 3.15 & 3.42 & 3.32 & 3.29 & 0.46 & 0.9 & 0.465 \\
\hline 31 & $\begin{array}{l}\text { Smart City has to be elaborated at } \\
\text { the regional level within the } \\
\text { framework of a Smart Region }\end{array}$ & 3.85 & 4.06 & 3.79 & 3.81 & 3.65 & 3.85 & 0.41 & 0.8 & 0.550 \\
\hline
\end{tabular}


Of the 31 statements, the five actors develop similar considerations on:

- The lowest difference- 0.17 - on a statement is recorded concerning the Smart City as a tool that improves governance principles (no. 15). The different categories of actors seem quite indistinct with an evaluation average of 3.19/5. This is confirmed by the results of the ANOVA test, which indicates that the differences between the means are not significant. (Sig. 0.956).

- Actors' opinions also coincide (2.88) along the affirmation that the administration is the best actor positioned to manage the local implementation of Smart City (no. 20) with a difference between them of 0.21 (ANOVA: Sig. 0.915).

They are also indecisive on a similar way concerning 'The development of Smart City which is largely relying on private consultancy' (no. 25) and that 'Large multinationals (IBM, Google, Uber, Accenture) primarily benefit from Smart City development' (no. 27) with respective values of 3.07 and 3.22 (ANOVA: Sig. 0.810 and 0.810$)$.

- They are poorly convinced (3.46) that Smart City is mainly based on the use of ICT, Big, and Open Data (no. 11), the difference between the categories of actors reaches only 0.33 (ANOVA: Sig. 0.658).

- Finally, actors have a quite similar opinion on the fact that Smart City will mobilize considerable financial resources in the coming years (no. 9). The difference between the categories of actors is low and is established at 0.38 with a shared opinion in favour between 3.74 and 4.00/5 (ANOVA: Sig. 0.454).

In contrast, there are differences of opinions between actors concerning certain subjects:

There is a disparity (1.03) on the claim that Smart City is an essential tool for branding towns, cities, and territories (no. 1). Numerous researchers do not accept this statement while a number of private companies strongly support the Smart City in this branding function. The results of the ANOVA test with a Sig. smaller than 0.05 confirms the difference of means between actors (Sig. 0.001). 
- The largest difference (1.37) recorded is opposing the categories on Smart City as a fashionable concept that may soon be outdated (no. 2). While several politicians and private companies are not convinced by a possible fading of Smart City, actors of the research and civil society largely agree on the fashionable vision and doubt the longterm effect of the concept (ANOVA: Sig. 0.001).

Finally, among others, the statement 'Smart City is directly related to increased competition between cities and territories' (no. 28) is characterized by an important difference (0.89) of appreciation between the categories of actors. Actors of the Civil Society perceive a risk whereas privates do not consider it as a threat (ANOVA: Sig. $0.012)$.

These results show that the different categories of actors have on average a harmonious vision on several topics concerning the Smart City. But their own positioning varies on specific statements. It shows a difference of appropriation on the concept that needs a deeper study. The next step offers the opportunity to refine the analysis and group statements inside a limited amount of determining factors so that further on it allows internal differences within some groups.

\subsection{Factor Analysis: Principal Component Analysis}

A Principal Component Analysis offers a logical grouping of proposals according to the actors' perception of the Smart City. The PCA is conducted on the 31 statements based on the eigenvalue criteria using the Varimax rotation (the rotated component matrix is available in Table 6 in the Appendix). It regroups the different statements when interviewees tend to react in a similar way to the statements. The Kaiser-Meyer-Olkin (KMO) and Bartlett's tests show for the measurement of sampling adequacy a significance rate of 0.763 (KMO). The PCA rotation reduces the number of factors from 31 statements to 11 factors thanks to the rotation. These factors explain $63.725 \%$ of the variance.

The reduction to 11 factors shows there is little association between the statements. It illustrates a certain independence between them. For each category of actors, the means of the 
11 factors' residuals are calculated and shown in Table 3. The 11 factors are labelled according to the meaning of the different statements composing each of them.

Table 3: Factors of the PCA

\begin{tabular}{|c|c|c|c|c|c|c|c|}
\hline$N$ & Factors & Statements & $\begin{array}{l}\text { Elected } \\
\text { Politics }\end{array}$ & $\begin{array}{c}\text { Admin \& } \\
\text { publics }\end{array}$ & Privates & $\begin{array}{l}\text { Research } \\
\text { \& Uni }\end{array}$ & $\begin{array}{c}\text { Civil } \\
\text { Society }\end{array}$ \\
\hline A & Smart City as a tool & $\begin{array}{c}3-5-7-1-10- \\
12-2-13\end{array}$ & 0.14 & -0.16 & 0.44 & -0.31 & -0.21 \\
\hline B & Smart City as a threat & $8-14-4-6-28$ & -0.24 & -0.28 & -0.05 & 0.25 & 0.50 \\
\hline C & $\begin{array}{c}\text { Smart City as a set of } \\
\text { actors }\end{array}$ & $17-16-25$ & 0.08 & 0.06 & -0.14 & -0.13 & 0.21 \\
\hline D & $\begin{array}{c}\text { Smart City as a concept for } \\
\text { cities }\end{array}$ & $30-31$ & 0.30 & -0.03 & 0.00 & -0.06 & -0.10 \\
\hline$E$ & $\begin{array}{c}\text { Smart City as based on } \\
\text { open governance }\end{array}$ & $22-23-15$ & -0.37 & 0.04 & -0.10 & 0.31 & 0.22 \\
\hline $\mathbf{F}$ & $\begin{array}{c}\text { Smart City as a structure } \\
\text { at a regional level }\end{array}$ & $18-31$ & 0.02 & -0.15 & 0.25 & -0.05 & -0.02 \\
\hline G & $\begin{array}{c}\text { Smart City as an } \\
\text { administrative procedure }\end{array}$ & 26 & -0.45 & 0.18 & 0.03 & 0.16 & -0.09 \\
\hline $\mathbf{H}$ & $\begin{array}{c}\text { Smart City as a potential } \\
\text { threat } \\
\text { (Too expensive, concurrence } \\
\text { and top-down) }\end{array}$ & $24-9-28$ & 0.24 & -0.02 & -0.17 & 0.10 & 0.04 \\
\hline 1 & $\begin{array}{c}\text { Smart City as a capture by } \\
\text { multinationals }\end{array}$ & 27 & -0.09 & 0.10 & -0.19 & 0.13 & 0.14 \\
\hline $\mathbf{J}$ & $\begin{array}{c}\text { Smart City as an } \\
\text { implementation by the } \\
\text { administration }\end{array}$ & 20 & 0.19 & -0.08 & 0.07 & -0.17 & 0.00 \\
\hline $\mathbf{K}$ & $\begin{array}{c}\text { Smart City as driven by } \\
\text { techno and start-ups }\end{array}$ & $21-11$ & -0.31 & 0.00 & 0.33 & -0.24 & -0.10 \\
\hline
\end{tabular}

Factor A integrates eight statements, it mainly considers the Smart City as a way to build and enhance the territory. This factor regroups statements highlighting the Smart City as a tool (no. 3-5-7-1-10-12) with green solutions (no. 13) and technological challenges (no. 10) which is not a fashionable concept soon outdated (no. 2).

The 11 factors obtained can be classified into the two types of instruments discussed in the theoretical framework. Three factors correspond to the technical and functionalist Instrument: A-I-K. These factors may be assimilated to a pragmatic set-up of the Smart City. The concept is apprehended as an adequate instrument for the development of cities and towns (A) with the involvement of some actors like multinationals and start-ups ( $\&$ K). These factors composed together a vision of the Smart City centred on a functionalist and technical implementation of the concept. There are no question and ethical considerations in these factors.

In contrast, four factors match with a public policy instrument approach $(\mathrm{B}, \mathrm{C}, \mathrm{E}, \mathrm{H})$. These instruments encompass two aspects, on one side, a critical reasoning on the 
construction of the Smart City and, on the other side, a call for specific development of the Smart City. The critical factors (B and H) comprise statements that highlight a Smart City with numerous menaces: threats on the rules of law and privacy, risk of privatization and hacking, danger of expensive spending and concurrence between territories, and finally menace of a potential top-down approach. These two factors put into perspective the Smart City under its potential negative effects. The two other factors ( $\mathrm{C}$ and $\mathrm{E}$ ) contain statements requesting a Smart City based on open governance and a mix of actors (privates, politics, and citizens) to manage it. These four factors feature the Smart City as a public policy instrument without neutrality and potentially producing negative effects on the society.

In these statistical results, four factors $(\mathrm{D}, \mathrm{F}, \mathrm{G}, \mathrm{J})$ are not yet clearly associated with an instrument with a public policy or a functionalist approach. These factors stress considerations for the construction of the Smart City based on territorial aspects (D \& F) and administrative process $(\mathrm{G} \& \mathrm{~J})$.

\section{$5.3 \quad K$-sort}

The k-sorting gathers relatively homogeneous actors sharing the same perceptions of the Smart City according to the 31 statements. The clustering is realized using the Two-Steps technique, which does not require pre-establishing the expected numbers of clusters before the treatment. One of the main outcomes of this clustering is that it generates only two groups. Further on, respondents are almost equally distributed across the two clusters as shown in Table 4.

The Pearson Chi-Square tests for three characteristics of actors are not statistically significant for genders and the three regions (Flanders, Brussels-Capital, and Wallonia). They are statistically significant for the categories of actors (Appendix 1). The numbers of respondents vary depending on the information furnished in the anonymous profile.

The results show an equal distribution of elected politicians among the two clusters. While a majority of actors coming from Civil Society, Research centres \& Universities and Administration \& Public organizations are located in the second cluster; private actors are mainly gathered in the first cluster.

Besides this, it is also possible to classify the 31 statements into groups. The differentiation of opinion on the statements between the two clusters of actors is the classifying characteristic. A two-sample $t$ test ( $t$ test for equality of means) determines the 
sorting calculation. Two groups emerge out of the statistical results; it shows that the clusters of actors have a different appropriation on 20 statements. The first group consists of 13 statements supporting a functional instrumental approach; the second one is composed of 7 statements offering a public policy instrumental approach. It misses 11 residual statements; they are not sorted because there is no independence. The actors' opinions are similar across the two clusters. They share a common appropriation on these statements, which mainly focus on governance aspects.

\section{Table 4}

Statements along the functionalist and public policy instruments (Cluster results)

\begin{tabular}{|c|c|c|c|c|c|c|}
\hline \multicolumn{7}{|c|}{ Group 1: Functionalist Instrument } \\
\hline $\mathbf{N}$ & Statements & $\begin{array}{l}\text { Mean } \\
\text { Group } 1\end{array}$ & $\begin{array}{l}\text { Mean } \\
\text { Group } 2\end{array}$ & $\begin{array}{l}\text { Means } \\
\text { difference }\end{array}$ & T-Value & P-Value \\
\hline 1 & $\begin{array}{l}\text { Smart City is an essential tool for branding towns, cities, and } \\
\text { territories }\end{array}$ & 2.94 & 3.89 & -0.95 & -6.167 & $<0.001$ \\
\hline 3 & $\begin{array}{l}\text { Smart City is an essential tool for the future of cities and towns } \\
\text { in Belgium }\end{array}$ & 3.18 & 4.49 & -1.31 & -10.243 & $<0.001$ \\
\hline 5 & $\begin{array}{l}\text { Smart City is an essential tool to enhance the sustainability of } \\
\text { cities and territories }\end{array}$ & 3.27 & 4.62 & -1.35 & -11.341 & $<0.001$ \\
\hline 7 & $\begin{array}{l}\text { Smart City is an essential tool to improve the quality of life of } \\
\text { inhabitants }\end{array}$ & 3.22 & 4.39 & -1.17 & -8.895 & $<0.001$ \\
\hline 10 & Smart City is a key technological challenge for cities and towns & 3.83 & 4.49 & -0.66 & -5.345 & $<0.001$ \\
\hline 11 & Smart City is mainly based on the use of ICT, Big, and Open Data & 3.16 & 3.79 & -0.63 & -4.321 & $<0.001$ \\
\hline 12 & Smart City is a tool to enhance transparency in decision-making & 2.73 & 3.82 & -1.09 & -6.928 & $<0.001$ \\
\hline 13 & Green technologies are part of Smart Cities solutions & 3.61 & 4.47 & -0.86 & -6.664 & $<0.001$ \\
\hline 15 & $\begin{array}{l}\text { Smart City improves governance principles (Decision-making, } \\
\text { actors' co-op, ...) }\end{array}$ & 2.86 & 3.39 & -0.53 & -3.809 & $<0.001$ \\
\hline 18 & $\begin{array}{l}\text { Smart City construction cannot start without the set-up of a } \\
\text { strategic plan }\end{array}$ & 3.17 & 3.59 & -0.42 & -3.515 & 0.001 \\
\hline 26 & $\begin{array}{l}\text { To accelerate the development of the Smart City, it is important } \\
\text { to lighten the administrative procedures }\end{array}$ & 3.00 & 3.29 & -0.29 & -1.965 & 0.051 \\
\hline 29 & Smart City can be adapted to any territory, including rural areas & 3.56 & 4.38 & -0.82 & -5.847 & $<0.001$ \\
\hline 31 & $\begin{array}{l}\text { Smart City has to be elaborated at the regional level within the } \\
\text { framework of a Smart Region }\end{array}$ & 3.59 & 4.08 & -0.49 & -2.989 & 0.003 \\
\hline \multicolumn{7}{|c|}{ Group 2: Public Policy Instrument } \\
\hline$N$ & Statements & $\begin{array}{l}\text { Mean } \\
\text { Group } 1\end{array}$ & $\begin{array}{l}\text { Mean } \\
\text { Group } 2\end{array}$ & $\begin{array}{l}\text { Means } \\
\text { difference }\end{array}$ & T-Value & P-Value \\
\hline 2 & $\begin{array}{l}\text { Smart City is a fashionable concept that may soon be } \\
\text { outdated }\end{array}$ & 3.07 & 1.88 & 1.19 & 7.557 & $<0.001$ \\
\hline 4 & $\begin{array}{l}\text { Smart City is related to the threat of privatization of } \\
\text { public spaces and public services }\end{array}$ & 3.09 & 1.97 & 1.12 & 6.734 & $<0.001$ \\
\hline 6 & $\begin{array}{l}\text { Smart City may further increase marginalization of } \\
\text { some inhabitants and social failures }\end{array}$ & 3.91 & 2.77 & 1.14 & 6.59 & $<0.001$ \\
\hline 8 & Smart City menaces regulation and rules of law & 2.88 & 1.99 & 0.89 & 5.966 & $<0.001$ \\
\hline 14 & $\begin{array}{l}\text { Smart City is a threat: it menaces privacy protection, } \\
\text { facilitates hacking, ... }\end{array}$ & 3.57 & 2.15 & 1.42 & 10.321 & $<0.001$ \\
\hline 28 & $\begin{array}{l}\text { Smart City is directly related to an increased } \\
\text { competition between cities and territories }\end{array}$ & 3.1 & 2.52 & 0.58 & 3.604 & $<0.001$ \\
\hline 30 & $\begin{array}{l}\text { Smart City will mainly benefit the large cities in } \\
\text { Belgium }\end{array}$ & 3.56 & 2.96 & 0.6 & 3.653 & $<0.001$ \\
\hline
\end{tabular}


Group 1 comprised 13 statements; they are highly supported by the actors of cluster 1 in comparison to the weak support registered by the actors of cluster 2 . The 13 statements emphasize the Smart City in two aspects. The actors of cluster 1 consider the Smart City as a tool useful for branding towns, enhancing sustainability, improving transparency, governance principles, and quality of life. They also consider it necessary to follow specific concrete directions to apply the concept to the territory. It consists of developing the Smart City using ICT, Data, and green technologies, as part of a local strategic plan, under the framework of a Smart region with a lightening of administrative procedures. The Smart City is adapted for them to any territory, including rural areas even if its implementation reveals a key technological challenge for cities and towns. This assortment of practical considerations advocates for a functionalist instrumental approach to the Smart City. The vision of these actors is centred on a functionalist and technical implementation of the concept without questioning the consequences of such an implementation.

Group 2 is composed of 7 statements. Actors in the first cluster do not clearly assent to these statements while the actors of the second cluster strongly support these proposals. They question the formation of a Smart City and stress some dangers in its implementation. For them, the Smart City is a fashionable concept which may mainly benefit large cities and increased competition between them. The Smart City is also a threat which may cause privatization of public spaces, a marginalization of some inhabitants, may facilitate hacking and may menace the regulation, rules of law, and privacy protection. All these considerations push to recognize the Smart City as a public policy instrument with potential (negative) value. For the actors of this cluster, the Smart City construction produces mainly undesirable effects on the society.

Table 5

Distribution of actors across the two clusters

\begin{tabular}{|c|c|c|c|c|c|c|}
\hline Clusters & $\begin{array}{c}\text { Elected } \\
\text { politicians }\end{array}$ & $\begin{array}{c}\text { Admin \& } \\
\text { public }\end{array}$ & Privates & $\begin{array}{c}\text { Research \& } \\
\text { Uni }\end{array}$ & Civil Society & Total \\
\hline \multirow[t]{2}{*}{1} & 12 & 21 & 35 & 10 & 13 & 91 \\
\hline & $46.2 \%$ & $40.4 \%$ & $67.3 \%$ & $33.3 \%$ & $41.9 \%$ & $47.6 \%$ \\
\hline \multirow[t]{2}{*}{2} & 14 & 31 & 17 & 20 & 18 & 100 \\
\hline & $53.8 \%$ & $59.6 \%$ & $32.7 \%$ & $66.7 \%$ & $58.1 \%$ & $52.4 \%$ \\
\hline \multirow[t]{2}{*}{ Total } & 26 & 52 & 52 & 30 & 31 & 191 \\
\hline & $100.0 \%$ & $100.0 \%$ & $100.0 \%$ & $100.0 \%$ & $100.0 \%$ & $100.0 \%$ \\
\hline
\end{tabular}


These results stress that there is not a clear distribution of categories of actors into one or the other cluster. Some slight trends exposed hereunder are pertinent but the distribution of profiles across the two clusters is not monolithic. However, the classification between functional and public policy instrumental appears relevant.

\section{Discussion}

The statistical results validate that the instrumental approach is pertinent to consider the concept of Smart City. The Belgian actors' appropriation of the Smart City supports the partition between two types of instrument, the functionalist and the public policy. The distributions of statements across the two instrumental approaches emerge mainly from the results of the CAP and the k-sorting statistical treatments.

However, both views converge in a Smart City as an instrument that proceeds the management and government of cities and territories. Some actors put tags and warnings for its implementation. As shown in the results of this study, the first necessary step is to investigate how actors appropriate these instruments before their implementation. Considerations on instruments offer the opportunity to question the circulation of ideas and models (Hood, 2007). The statistical results show that the actors' appropriation is operated in different directions.

The results highlight that some actors consider the Smart City as a functionalist instrument. Smart City is appropriate as a management device for a city and territory based on an efficient mode of governance where complex social problems can be solved or optimized (Kitchin, 2014). This actors' appropriation corresponds to a functional instrumental approach where the Smart City is considered as a kind of evidence, 'at disposal', and conceived as a pragmatic political and technical approach to solve problems (Lascoumes \& Le Gales, 2007), what Morozov (2013) calls 'solutionism'. The Smart City in this perspective is a denaturalized technical object, neutral, equally available and without political value and consequences. It is a pragmatic solution, a device utilized to transform the territory.

The results also underline that some actors consider that the Smart City should be conceived as a public policy instrument. The actors' appropriation shows an ideological dimension of the Smart City. They mainly stress their own force of action and the potential effect of the Smart City (Lascoumes \& Le Gales, 2007). Their appropriations focus on the consequences of the Smart City as an instrument that impacts territories and societies. They 
mainly concentrate on the potential negative effects. The underlined elements are pointed out by a restrictive and critical school of thought (Kummitha \& Crutzen, 2017). The Smart City is not purely technical, inert, and with perfect axiological neutrality (Lascoumes \& Simard, 2011). On the contrary, the Smart City is full of values questioning the future of cities and towns. The Smart City is an instrument full of consequences provoking debates on political goals, influencing policies, and affecting actors' resources.

Smart City is not perceived by actors as a binary path between a technological approach and a holistic approach. For Belgian actors, Smart City does not follow a dual development. In addition, the Smart City is not assimilated as following a soft or a hard direction (Albino et al., 2015) where technologies play a decisive role. Nuances are needed in the Belgian actors' appropriation. Indeed, actors are not clustered in one or in the other conception and direction of the Smart City. They follow, on the one hand, a partition following the two types of instruments, and on the other hand, a division and associations of actors on certain topics. In fact, the association/division of actors does not follow a homogeneous trend.

The assumptions made by the authors are verified. The Smart City considered as functionalist and public policy instruments by Belgian actors corroborates with the statistical results. Politicians \& public servants, private actors, members of the civil society, and researchers appropriate the Smart City through the two types of instruments. However, there are differences of appropriation inside the categories of actors. Their role in the decisionmaking process, their level of development in Smart City initiatives (mature versus emerging) and their ideological background may have a potential effect on their appropriation of the Smart City.

Finally, this study focuses on the entire Belgian territory. It makes it possible to take into account the verticality of relationships between actors, which is missing in many scientific analyses of Smart Cities. This verticality is taken into account thanks to the variety of respondents. But Belgium as a case study requests critical considerations to extend the analysis to other territories and actors. It is necessary to take into account the intrinsic characteristics of the country, such as the institutional complexity, the dense network of small- and medium-sized cities, the mix of urban and rural territories, the important periurbanization phenomena and the open economy. However, this article offers a new research path and scope circumventing these differences in focusing directly on the Belgian actors involved in the Smart City dynamics across the territory. The respondents embody the 
representativeness of the rich economic, social, political, and cultural diversity at the regional and local levels, which is indirectly taken into consideration in the study. Another limitation concerns the temporal factor of the study. Indeed, this article takes the pulse of Belgian actors at a given moment on a fixed territory. It does not take into account the dynamics and processes existing in time. Actors' positioning and appropriation of the Smart City development is a fixed picture. In addition, the representativeness of the actors interviewed is not measurable.

Nevertheless, this article offers a comprehensive view of the multifaceted Smart City by its practitioners. It allows an identification of actors' appropriation of the Smart City through an instrumental approach theorized by Lascoumes \& Le Gales (2007). It encompasses also their common and opposite opinions on the territorial, societal, and practical development of the Smart City.

\section{Conclusion}

This paper questions in an innovative way the Smart City appropriation by actors. Smart City is often perceived as a development of the territory pushed on the one hand by technologies and on the other by a holistic development that includes a whole series of notions such as sustainable development, governance, human centred ... This study stands out from these conceptualizations and uses the Instrument theory conceived by Lascoumes \& Le Gales (2007).

In this paper, the Smart City is considered as an instrument of territorial construction. The question that arises is how do actors appropriate the Smart City as types of instrument? Is It a functional instrument: a kind of evidence, a denaturalized technical object, and a pragmatic solution at disposal or a public policy instrument: not neutral, provoking debates on political goals, influencing policies, affecting actors' resources?

On the basis of an online survey with 193 Belgian respondents, the results of different statistical treatments carried out demonstrate that:

- First, the use of Instrument theory is relevant. The positioning of actors on the questionnaire's statements follows the logic of the functional and public policy instruments. 
- Second, Smart City actors do not fit into one or the other category of instrument in a monolithic way. Trends emerge for some actors and verify the assumptions proposed by the authors.

- Third, in some cases actors oppose certain conceptualizations of the Smart City and in others form coalitions of opinions.

These results show that the actors' appropriation of the Smart City does not follow a homogeneous trend based on either a technical or a holistic direction. It is necessary to nuance the current affirmations on actors' consideration in the Smart City literature. In fact, each actor follows his own logic. The theoretical lenses used in this article are older than the concept of Smart City itself and thus provide insights to study it. Undeniably, this paper contributes to the Smart City literature by analysing through instruments the Smart City as a public policy instrument on one side versus a functional instrument on the other side.

To go further in the analysis of the Smart City as an instrument, and to take into account the dynamics and processes underlying Smart City appropriation, it will be necessary to study the impacts of the actors' role in the decision-making process, actors' level of development in Smart City initiatives (mature versus emerging) and actors' ideological background.

\section{References}

Ahvenniemi, H., Huovila, A., Pinto-Seppä, I., \& Airaksinen, M. (2017). What are the differences between sustainable and smart cities? Cities, 60. 234-245. http://doi.org/10.1016/j.cities.2016.09.009

Alawadhi, S., Aldama-Nalda, A., Chourabi, H., Gil-Garcia, J. R., Leung, S., Mellouli, S., ... Walker, S. (2012). Building understanding of smart city initiatives. Lecture Notes in Computer Science, 7443 LNCS, 40-53. http://doi.org/10.1007/978-3-642-33489-4_4

Albino, V., Berardi, U., \& Dangelico, R. M. (2015a). Smart Cities: Definitions, Dimensions, Performance, and Initiatives. Journal of Urban Technology, 22(1), 3-21. http://doi.org/10.1080/10630732.2014.942092

Angelidou, M. (2014). Smart city policies: A spatial approach. Cities, 41. S3-S11. http://doi.org/10.1016/j.cities.2014.06.007

Angelidou, M. (2015). Smart cities: A conjuncture of four forces. Cities, 47, 95-106. http://doi.org/10.1016/j.cities.2015.05.004

Angelidou, M. (2017). The Role of Smart City Characteristics in the Plans of Fifteen Cities. Journal of Urban Technology, 24(4), 3-28. http://doi.org/10.1080/10630732.2017.1348880

Araya, D. (2015). Smart cities and the network society: Toward commons-driven governance. Smart Cities as Democratic Ecologies, 11-22. http://doi.org/10.1057/9781137377203

Ballas, D. (2013). What makes a 'happy city'? Cities. http://doi.org/10.1016/j.cities.2013.04.009 
Barns, S. (2018). City , Culture and Society Smart cities and urban data platforms : Designing interfaces for smart governance. City, Culture and Society, 12(September 2017), 5-12.

http://doi.org/10.1016/j.ccs.2017.09.006

Bătăgan, L. (2011). Smart Cities and Sustainability Models. Revista de Informatică Economică, 15(3), 80-87. Retrieved from http://revistaie.ase.ro/content/59/07 - Batagan.pdf

Batty, M., Axhausen, K. W., Giannotti, F., Pozdnoukhov, A., Bazzani, A., Wachowicz, M., ... Portugali, Y. (2012). Smart cities of the future. European Physical Journal: Special Topics, 214(1), 481-518. http://doi.org/10.1140/epjst/e2012-01703-3

Ben Letaifa, S. (2015b). How to strategize smart cities: Revealing the SMART model. Journal of Business Research, 68(7), 1414-1419. http://doi.org/10.1016/j.jbusres.2015.01.024

Bolívar, M. P. (2017). Governance Models and Outcomes to Foster Public Value Creation in Smart Cities. 18th Annual International Conference on Digital Government Research (Dg.o 2017), 17, 521-530. http://doi.org/10.1145/3085228.3085310

Caragliu, A., \& Del Bo, C. (2018a). The economics of smart city policies. Scienze Regionali, 17(1), 81-104. http://doi.org/10.14650/88818

Caragliu, A., \& Del Bo, C. F. (2016). Do Smart Cities Invest in Smarter Policies? Learning From the Past, Planning for the Future. Social Science Computer Review, 34(6), 657-672. http://doi.org/10.1177/0894439315610843

Caragliu, A., \& Del Bo, C. F. (2018b). Smart innovative cities: The impact of Smart City policies on urban innovation. Technological Forecasting and Social Change, (December 2017), 1-11. http://doi.org/10.1016/j.techfore.2018.07.022

Chatfield, A. T., \& Reddick, C. G. (2015). Smart City Implementation Through Shared Vision of Social Innovation for Environmental Sustainability: A Case Study of Kitakyushu, Japan. Social Science Computer Review, 34(6), 1-17. http://doi.org/10.1177/0894439315611085

Chourabi, H., Nam, T., Walker, S., Gil-Garcia, J. R., Mellouli, S., Nahon, K., ... Scholl, H. J. (2011). Understanding smart cities: An integrative framework. Proceedings of the Annual Hawaii International Conference on System Sciences, 2289-2297. http://doi.org/10.1109/HICSS.2012.615

Termeer Cjam, \& Koppenjan Joop . (1997). Managing perceptions in networks. In Managing Complex Networks: Strategies for the Public Sector. http://doi.org/10.4135/9781446217658.n5

Cugurullo, F. (2018). Exposing smart cities and eco-cities: Frankenstein urbanism and the sustainability challenges of the experimental city. Environment and Planning $A$. http://doi.org/10.1177/0308518X17738535

Dameri, R. P. (2017). Urban Smart Dashboard. Measuring Smart City Performance. Smart City Implementation. http://doi.org/10.1007/978-3-319-45766-6

Dameri, R.P. (2013). Searching for Smart City definition: a comprehensive proposal. International journal of Computers \& Technology, 11(5), 2544-2551. https://doi.org/10.24297/ijct.v11i5.1142

Deakin, M. (2014). Smart cities: the state-of-the-art and governance challenge. Theoretical Chemistry Accounts, 1(1), 1-16. http://doi.org/10.1186/s40604-014-0007-9

Gardon S., Lascoumes P., Le Galès P. (2007). Gouverner par les instruments. In: Politiques et management public, vol. 25, n², 2007. pp. 145-150. Retrieved from http://www.persee.fr/doc/pomap_07581726_2007_num_25_2_3222 
Garau, C., \& Pavan, V. M. (2018). Evaluating urban quality: Indicators and assessment tools for smart sustainable cities. Sustainability (Switzerland), 10(3). http://doi.org/10.3390/su10030575

Gil-Garcia, J. R., Pardo, T. A., \& Nam, T. (2015). What makes a city smart? Identifying core components and proposing an integrative and comprehensive conceptualization. Information Polity, 20(1), 61-87. http://doi.org/10.3233/IP-150354

Gil-Garcia, J. R., Pardo, T. A., \& Nam, T. (2016). Smarter as the New Urban Agenda: A Comprehensive View of the 21st Century City. Computer Law \& Security Review. http://doi.org/10.1016/S0267-3649(96)90014-X

Gil-Garcia, J. R., Zhang, J., \& Puron-Cid, G. (2016). Conceptualizing smartness in government: An integrative and multi-dimensional view. Government Information Quarterly, 33(3), 524-534. http://doi.org/10.1016/j.giq.2016.03.002

Girard, L. F. (2013). Toward a smart sustainable development of port cities/areas: The role of the 'Historic Urban Landscape' approach. Sustainability (Switzerland), 5(10), 4329-4348. http://doi.org/10.3390/su5104329

Greenfield, A. (2013). Against the Smart City. In The City is Here for You to Use. http://doi.org/10.29146/ecopos.v20i3.14481

Hollands. (2008). Will the real smart city please stand up? City, 12(3), 303-320. http://doi.org/10.1080/13604810802479126

Hollands, (2015). Critical interventions into the corporate smart city. Cambridge Journal of Regions Economy and Society, 8(1), 61-77. http://doi.org/DOI 10.1093/cjres/rsu011

Hood, C. (2007). Intellectual obsolescence and intellectual makeovers: Reflections on the tools of government after two decades. Governance, 20(1), 127-144. http://doi.org/10.1111/j.1468-0491.2007.00347.x

Ibrahim, M., El-Zaart, A., \& Adams, C. (2018). Smart sustainable cities roadmap: Readiness for transformation towards urban sustainability. Sustainable Cities and Society, 37(September 2017), 530-540. http://doi.org/10.1016/j.scs.2017.10.008

Kitchin, R. (2014). The real-time city? Big data and smart urbanism. GeoJournal, 79(1), 1-14. http://doi.org/10.1007/s10708-013-9516-8

Kitchin, R. (2015). Making sense of smart cities: addressing present shortcomings. Cambridge Journal of Regions, Economy and Society, 8(1), 131-136. http://doi.org/10.1093/cjres/rsu027

Kourtit, K., \& Nijkamp, P. (2012). Smart cities in the innovation age. Innovation: The European Journal of Social Science Research, 25(2), 93-95. http://doi.org/10.1080/13511610.2012.660331

Kourtit, K., \& Nijkamp, P. (2018). Land Use Policy Big data dashboards as smart decision support tools for i cities - An experiment on stockholm. Land Use Policy, 71(October 2017), 24-35. http://doi.org/10.1016/j.landusepol.2017.10.019

Kramers, A., Höjer, M., Lövehagen, N., \& Wangel, J. (2014). Smart sustainable cities - Exploring ICT solutions for reduced energy use in cities. Environmental Modelling and Software, 56, 52-62. http://doi.org/10.1016/j.envsoft.2013.12.019

Kummitha, R. K. R., \& Crutzen, N. (2017). How do we understand smart cities? An evolutionary perspectiveKummitha, R. K. R., \& Crutzen, N. (2017). How do we understand smart cities? An evolutionary perspective. Cities, 67(March), 43-52. http://doi.org/10.1016/j.cities.2017.04.010.

Lascoumes, P., \& Le Gales, P. (2007). Introduction: Understanding Public Policy through Its Instruments?From the Nature of Instruments to the Sociology of Public Policy Instrumentation. Governance, 20(1), 1-21. 
http://doi.org/10.1111/j.1468-0491.2007.00342.x

Lascoumes, P., Le Galès, P., Gardon, S., Sébastien Pierre Lascoumes, G., \& Le, P. (2007). Politiques et management public par les instruments, 25(2), 145-150. Retrieved from http://www.persee.fr/doc/pomap_0758-1726_2007_num_25_2_3222

Lascoumes, P., \& Simard, L. (2011). L'action publique au prisme de ses instruments. Revue Française de Science Politique. http://doi.org/10.3917/rfsp.611.0005

Lascoumes, P., \& Valluy, J. (1996). Les activités publiques conventionnelles (APC) : un nouvel instrument de politique publique? L'exemple de la protection de l'environnement industriel. Sociologie Du Travail. http://doi.org/10.2307/43150275

Lombardi, P., Giordano, S., Farouh, H., \& Yousef, W. (2012). Modelling the smart city performance. Innovation: The European Journal of Social Science Research, 25(2), 137-149. http://doi.org/10.1080/13511610.2012.660325

Luque-Ayala, A., \& Marvin, S. (2015). Developing a critical understanding of smart urbanism? Urban Studies, 52(12), 2105-2116. http://doi.org/10.1177/0042098015577319

Mannaro, K., Baralla, G., \& Garau, C. (2018). A Goal-Oriented Framework for Analyzing and Modeling City Dashboards in Smart Cities. Springer International Publishing. http://doi.org/10.1007/978-3-319-75774-2

Manville, C., Cochrane, G., Cave, J., Millard, J., Thaarup, R. kare, Liebe, A., ... Kotterink, B. (2014). Mapping Smart Cities in the EU STUDY. European Parliament.

Marsal-Llacuna, M. L., \& Wood-Hill, M. (2017). The Intelligenter method (III) for smarter standards development and standardisation instruments. Computer Standards and Interfaces, 50 (October 2016), 142-152. http://doi.org/10.1016/j.csi.2016.09.010

Mattern, S. (2013). Methodolatry and the Art of Measure: The new wave of urban data science. Places Journal, November 2013. https://doi.org/10.22269/131105

Mcfarlane, C. (2011). Learning the City: Knowledge and Translocal Assemblage. Learning the City: Knowledge and Translocal Assemblage. http://doi.org/10.1002/9781444343434

Meijer, A., \& Bolivar, M. P. R. (2015). Governing the smart city: a review of the literature on smart urban governance. International Review of Administrative Sciences, 0020852314564308-. http://doi.org/10.1177/0020852314564308

Mora, L., Bolici, R., \& Deakin, M. (2017). The First Two Decades of Smart-City Research: A Bibliometric Analysis. Journal of Urban Technology, (March). http://doi.org/10.1080/10630732.2017.1285123

Morozov, E. (2013). The 'sharing economy' undermines workers' rights. The Financial Times.

Nam, T., \& Pardo, T. a. (2011). Conceptualizing smart city with dimensions of technology, people, and institutions. Proceedings of the 12th Annual International Digital Government Research Conference on Digital Government Innovation in Challenging Times - Dg.o '11. 282. http://doi.org/10.1145/2037556.2037602

O'Grady, M., \& O'Hare, G. (2012). How smart is your city?, Science, 2012; 335 (6076):1581-2 9-11. http://doi.org/10.1126/science.1217637

Paskaleva, K. A. (2011). The smart city: A nexus for open innovation? Intelligent Buildings International, 3(3), 153-171. http://doi.org/10.1080/17508975.2011.586672

Paskaleva, K., Cooper, I., Peterson, B., \& Götz, C. (2015). Actor Engagement in the Smart City: Making Living 
Labs Work. In M. P. Rodríguez-Bolívar (Ed.), Transforming City Governments for Successful Smart Cities (pp. 115-145). http://doi.org/10.1007/978-3-319-03167-5

Pinson, G. (2006). Projets de ville et gouvernance urbaine. Pluralisation des espaces politiques et recomposition d'un capacité d'action collective dans les villes européennes. Revue française de science politique (Vol. 56). http://doi.org/10.3917/rfsp.564.0619

Praharaj, S., Han, J. H., \& Hawken, S. (2018). Urban innovation through policy integration: Critical perspectives from 100 smart cities mission in India. City, Culture and Society. http://doi.org/10.1016/j.ccs.2017.06.004

Rai, A., \& Challa, R. K. (2016). Advanced Computing and Communication Technologies, 452. 345-358. http://doi.org/10.1007/978-981-10-1023-1

Ramaswami, A., Russell, A. G., Culligan, P. J., Sharma, K. R., \& Kumar, E. (2016). Meta-principles for developing smart, sustainable, and healthy cities. Science, 352(6288), 940-943. http://doi.org/10.1126/science.aaf7160

Rodríguez-Bolívar, M. P. (2015). Transforming city governments for successful smart cities. In M. P. RodríguezBolívar (Ed.), Transforming City Governments for Successful Smart Cities (pp. 1-185). http://doi.org/10.1007/978-3-319-03167-5

Rodríguez Bolívar, M. P. (2018). Governance models and outcomes to foster public value creation in smart cities. Scienze Regionali. http://doi.org/10.14650/88817

Salamon, L. M, \& Elliott, O. V. (2002). The tools of government : a guide to the new governance. Oxford: Oxford University Press.

Schaffers, H., Komninos, N., Pallot, M., Trousse, B., Nilsson, M., \& Oliveira, A. (2011). Smart Cities and the Future Internet: Towards Cooperation Frameworks for Open Innovation. In The Future Internet (Vol. 6656, pp. 431-446). http://doi.org/10.1007/978-3-642-20898-0

Söderström, O., Paasche, T., \& Klauser, F. (2014). Smart cities as corporate storytelling. City, 18(3), 307-320. http://doi.org/10.1080/13604813.2014.906716

Suakanto, S., Supangkat, S. H., Suhardi, \& Saragih, R. (2013). Smart city dashboard for integrating various data of sensor networks. In Proceedings - International Conference on ICT for Smart Society 2013: 'Think Ecosystem Act Convergence', ICISS 2013. http://doi.org/10.1109/ICTSS.2013.6588063

Termeer Cjam, \& Koppenjan Joop . (1997). Managing perceptions in networks. In Managing Complex Networks: Strategies for the Public Sector. http://doi.org/10.4135/9781446217658.n5

Townsend, A. (2013) Smart Cities: Big Data, Civic Hackers, and the Quest for a New Utopia, New York City, .W. Norton \& Company Ltd.

Vanolo, A. (2014). Smartmentality: The Smart City as Disciplinary Strategy. Urban Studies, 51(5), 883-898. http://doi.org/10.1177/0042098013494427

Yates, D. (1977). The ungovernable city : the politics of urban problems and policy making. Cambridge, MIT press. http://doi.org/10.1177/000271627843900152

Yigitcanlar, T. (2017). Smart cities : an effective urban development and management model ? Australian Planner, 52(1), 27-34. http://doi.org/10.1080/07293682.2015.1019752 


\section{Appendix}

\section{Table 5}

Results of clustering calculation.

\begin{tabular}{|r|r|c|c|}
\hline Clusters & $\mathbf{N}$ & $\begin{array}{r}\text { \% } \\
\text { Combined }\end{array}$ & \% Total \\
\hline 1 & 101 & $52.3 \%$ & $51.3 \%$ \\
2 & 92 & $47.7 \%$ & $46.7 \%$ \\
\hline Combined & 193 & $100.0 \%$ & $98.0 \%$ \\
Excluded & 4 & & $2.0 \%$ \\
\hline
\end{tabular}

\section{Table 6}

Results of clustering calculation across three variables.

\begin{tabular}{|c|c|c|c|c|c|c|}
\hline Tests & \multicolumn{2}{|c|}{ Actors' categories } & \multicolumn{2}{|c|}{ Regions } & \multicolumn{2}{|c|}{ Genders } \\
\hline Chi-Square & Value & Asymp. Sig. & Value & Asymp. Sig. & Value & Asymp. Sig. \\
\hline Pearson Chi-Square & 12.05 & 0.017 & 2.826 & 0.419 & 1.76 & 0.184 \\
\hline Likelihood Ratio & 12.234 & 0.016 & 2.853 & 0.415 & 1.764 & 0.184 \\
\hline Linear-by-Linear Assoc & 0.139 & 0.709 & 1.379 & 0.24 & 1.754 & 0.185 \\
\hline Phi & 0.251 & 0.017 & 0.121 & 0.419 & -0.096 & 0.184 \\
\hline Cramer's V & 0.251 & 0.017 & 0.121 & 0.419 & 0.096 & 0.184 \\
\hline$N$ of Valid Cases & \multicolumn{2}{|r|}{191} & \multicolumn{2}{|r|}{192} & \multicolumn{2}{|c|}{192} \\
\hline
\end{tabular}

Table 7

PCA Rotated Component Matrix.

\begin{tabular}{|c|c|c|c|c|c|c|c|c|c|c|c|c|}
\hline \multicolumn{13}{|c|}{ Rotated Component Matrix } \\
\hline \multicolumn{2}{|r|}{ Statements/Components } & 1 & 2 & 3 & 4 & 5 & 6 & 7 & 8 & 9 & 10 & 11 \\
\hline 1 & $\begin{array}{l}\text { Smart City is an essential tool for } \\
\text { branding towns, cities, and territories }\end{array}$ & 0.68 & & & & & & & & & & \\
\hline 2 & $\begin{array}{l}\text { Smart City is a fashionable concept } \\
\text { that may soon be outdated }\end{array}$ & -0.554 & & & & & & & & & & \\
\hline 3 & $\begin{array}{l}\text { Smart City is an essential tool for the } \\
\text { future of cities and towns in Belgium }\end{array}$ & 0.812 & & & & & & & & & & \\
\hline 4 & $\begin{array}{l}\text { Smart City is related to the threat of } \\
\text { privatization of public spaces and } \\
\text { public services }\end{array}$ & & 0.625 & & & & & & & & & \\
\hline 5 & $\begin{array}{l}\text { Smart City is an essential tool to } \\
\text { enhance the sustainability of cities } \\
\text { and territories }\end{array}$ & 0.798 & & & & & & & & & & \\
\hline 6 & $\begin{array}{l}\text { Smart City may further increase } \\
\text { marginalization of some inhabitants } \\
\text { and social failures }\end{array}$ & & 0.46 & & & & & & & & & \\
\hline 7 & $\begin{array}{l}\text { Smart City is an essential tool to } \\
\text { improve the quality of life of } \\
\text { inhabitants }\end{array}$ & 0.777 & & & & & & & & & & \\
\hline 8 & $\begin{array}{l}\text { Smart City menaces regulation and } \\
\text { rules of law }\end{array}$ & & 0.732 & & & & & & & & & \\
\hline 9 & $\begin{array}{l}\text { Smart City will mobilize considerable } \\
\text { financial resources in the coming } \\
\text { years }\end{array}$ & & & & & & & & 0.569 & & & \\
\hline 10 & $\begin{array}{l}\text { Smart City is a key technological } \\
\text { challenge for cities and towns }\end{array}$ & 0.652 & & & & & & & & & & \\
\hline 11 & Smart City is mainly based on the use & & & & & & & & & & & 0.615 \\
\hline
\end{tabular}




\begin{tabular}{|c|c|c|c|c|c|c|c|c|c|c|c|c|}
\hline & of ICT, Big, and Open Data & & & & & & & & & & & \\
\hline 12 & $\begin{array}{l}\text { Smart City is a tool to enhance } \\
\text { transparency in decision-making }\end{array}$ & 0.627 & & & & & & & & & & \\
\hline 13 & $\begin{array}{l}\text { Green technologies are part of Smart } \\
\text { Cities solutions }\end{array}$ & 0.539 & & & & & & & & & & \\
\hline 14 & $\begin{array}{l}\text { Smart City is a threat: it menaces } \\
\text { privacy protection, facilitates } \\
\text { hacking, ... }\end{array}$ & & 0.626 & & & & & & & & & \\
\hline 15 & $\begin{array}{l}\text { Smart City improves governance } \\
\text { principles (Decision-making, actors' } \\
\text { co-operation, ...) }\end{array}$ & & & & & 0.476 & & & & & 0.453 & \\
\hline 16 & $\begin{array}{l}\text { Smart City should be based on } \\
\text { initiatives led by civil society actors } \\
\text { (citizens, associations) }\end{array}$ & & & 0.584 & & & & 0.427 & & & & \\
\hline 17 & $\begin{array}{l}\text { Local government should play a } \\
\text { leading role in the Smart City } \\
\text { development }\end{array}$ & & & 0.737 & & & & & & & & \\
\hline 18 & $\begin{array}{l}\text { Smart City construction cannot start } \\
\text { without the setup of a strategic plan }\end{array}$ & & & & & & 0.665 & & & & & \\
\hline 19 & $\begin{array}{l}\text { Smart City should entail a sharing of } \\
\text { power between the different actors }\end{array}$ & & & & & & & & & & & \\
\hline 20 & $\begin{array}{l}\text { Administration is the best actor } \\
\text { positioned to manage local } \\
\text { implementation of Smart City } \\
\text { strategy and solutions }\end{array}$ & & & & & & & & & & 0.8 & \\
\hline 21 & $\begin{array}{l}\text { Smart City cannot be developed } \\
\text { without local startups and } \\
\text { entrepreneurs }\end{array}$ & & & & & & & & & & & 0.759 \\
\hline 22 & $\begin{array}{l}\text { Research centres and universities are } \\
\text { essential contributors to Smarter } \\
\text { cities and towns }\end{array}$ & & & & & 0.689 & & & & & & \\
\hline 23 & $\begin{array}{l}\text { Smart City should be based on a } \\
\text { balanced mix of projects from public } \\
\text { authorities and projects from } \\
\text { citizens, associations, and private } \\
\text { companies }\end{array}$ & & & & & 0.689 & & & & & & \\
\hline 24 & $\begin{array}{l}\text { Smart City is primarily a political } \\
\text { process involving elected officials }\end{array}$ & & & & & & & & 0.815 & & & \\
\hline 25 & $\begin{array}{l}\text { The development of Smart City is } \\
\text { largely relying on private consultancy }\end{array}$ & & & 0.404 & & & & & & & & \\
\hline 26 & $\begin{array}{l}\text { To accelerate the development of the } \\
\text { Smart City, it is important to lighten } \\
\text { the administrative procedures }\end{array}$ & & & & & & & 0.848 & & & & \\
\hline 27 & $\begin{array}{l}\text { Large multinationals (IBM, Google, } \\
\text { Uber, Accenture) primarily benefit } \\
\text { from Smart City development }\end{array}$ & & & & & & & & & 0.833 & & \\
\hline 28 & $\begin{array}{l}\text { Smart City is directly related to an } \\
\text { increased competition between cities } \\
\text { and territories }\end{array}$ & & 0.413 & & & & & & 0.428 & & & \\
\hline 29 & $\begin{array}{l}\text { Smart City can be adapted to any } \\
\text { territory, including rural areas }\end{array}$ & & & & $\begin{array}{l}- \\
0.612\end{array}$ & & & & & & & \\
\hline 30 & $\begin{array}{l}\text { Smart City will mainly benefit the } \\
\text { large cities in Belgium }\end{array}$ & & & & 0.842 & & & & & & & \\
\hline 31 & $\begin{array}{l}\text { Smart City has to be elaborated at } \\
\text { the regional level within the } \\
\text { framework of a Smart Region }\end{array}$ & & & & & & 0.588 & & & & & \\
\hline & hethod: Varimax with Kais & & & & & & & & & & & \\
\hline
\end{tabular}

